\title{
Unia polsko-czechosłowacka i jej zasady ustrojowe jako model systemu bezpieczeństwa kolektywnego
}

\author{
The Polish-Czechoslovak Union and Its Political Principles \\ as a Model of a Collective Security System
}

\section{- Abstrakt •}

Losy państwa czechosłowackiego z marca 1939 r. i państwa polskiego z września tego roku uświadomiły politykom Polski i Czechosłowacji konieczność podjęcia próby stworzenia systemu obrony kolektywnej, który w rzeczywistości powojennej skutecznie ochroniłby je przed atakami silniejszych sąsiadów. Mimo istniejących uprzedzeń i bezowocnych wysiłków podejmowanych w okresie międzywojennym czescy i słowaccy politycy podjęli sondażowe kontakty $\mathrm{z}$ polskim rządem emigracyjnym już $\mathrm{w}$ początkach października 1939 r. Z uwagi jednak na brak jednolitej reprezentacji politycznej państwa czechosłowackiego wobec aliantów wzajemne spotkania mogły się ograniczać jedynie do wymiany poglądów. Dopiero uznanie Czechosłowackiego Komitetu Narodowego, pod przywództwem Edvarda Beneša, przez Wielką Brytanię i Francję za jedyną reprezentację Republiki Czechosłowackiej stworzyło możliwość podjęcia bardziej konkretnych rozmów. Ich efektem było opracowanie przez Komitet Polityczny Rady Ministrów Zasad Aktu Konstytucyjnego Związku Polski i Czechosłowacji. W dokumencie tym

\section{- Abstract •}

The aggression of Hitler's Germany and Soviet Russia made the politicians of Poland and Czechoslovakia aware of the need to create a collective security system that would effectively protect them from the attacks of their stronger states after the war. In the beginnings of October 1939, Czech and Slovak politicians started polling contacts with the Polish government in exile. However, due to the lack of a uniform political representation of the Czechoslovak state towards the Allies, the meetings could be limited to an exchange of views. Only the recognition of the Czechoslovak National Committee, led by Edvard Beneš, by Great Britain and France as the only representation of the Czechoslovak Republic created the opportunity for more concrete talks. As a result, the Political Committee of the Council of Ministers developed the Principles of the Constitutional Act of the Union of Poland and Czechoslovakia. In this document, proposals for the principles of the political system of the proposed union were presented, including those in the field of defence. Due to the fact that the project provided for the possibility 
przedstawiono propozycje zasad ustrojowych projektowanej unii, w tym w zakresie obronności. W związku z tym, że w projekcie przewidywano możliwość rozszerzenia projektowanej unii o inne państwa Europy Środkowej, przedstawione regulacje stanowity projekt modelowych rozwiązań $\mathrm{w}$ zakresie stworzenia w tym regionie kontynentu systemu obrony kolektywnej. Tym kwestiom poświęcony jest niniejszy artykuł.

Słowa kluczowe: obrona kolektywna; II wojna światowa; stosunki polsko-czechosłowackie; unia polsko-czechosłowacka of extending the proposed union to other Central European states, the presented regulations constituted a project of model solutions for the creation of a collective defence system in this region of the continent. The article is devoted to these issues.

Keywords: collective defence; World War II; Polish-Czechoslovak relations; Polish-Czechoslovak union

Stosunki polsko-czechosłowackie z okresu poprzedzającego wybuch II wojny światowej oraz w trakcie trwania tego konfliktu od dawna wzbudzają zainteresowanie badaczy. Szczególne miejsce w badaniach nad tym zagadnieniem zajmowała kwestia projektu utworzenia konfederacji polsko-czechosłowackiej. W powstałej, na podstawie dokonanych ustaleń, literaturze koncentrowano się głównie na problemach politycznych związanych z tą koncepcją. Na uboczu tych rozważań pozostawała kwestia próby skonstruowania systemu obrony kolektywnej obu państw.

Polityczne aspekty zarysowanego problemu zostały całościowo podjęte w pracy traktującej o całokształcie stosunków polsko-czechosłowackich w latach 1939-1943 w warunkach emigracyjnych (Kamiński, 2005). Podobnie istotnych kwestii w odniesieniu do projektowanej unii dotyczy monografia, w której omówiono pertraktacje polsko-czechosłowackie w latach 1939-1943 (Kisielewski, 1991). W ostatnich latach podjęto się monograficznego opracowania problematyki politycznej związanej z projektem unii polsko-czechosłowackiej (Kolendo, 2015). Na uwagę zasługują publikacje Henryka Batowskiego, Włodzimierza T. Kowalskiego i Stanisława Zabiełły, w których poruszone zostały kwestie stosunków polsko-czechosłowackich na emigracji w aspekcie międzynarodowego charakteru sprawy polskiej w okresie II wojny światowej (Batowski, 1984; Kowalski, 1979; Zabiełło, 1970). Cenną, jak się wydaje, publikacją była praca prezentująca problematykę unii obu państw na tle kontaktów gen. Sikorskiego z prezydentem Edvardem Benešem (Wandycz, 1956). Niewątpliwą jej słabością było niewykorzystanie dostępnej spuścizny archiwalnej, co spowodowało, że nie była ona w pełni obiektywna. Podobny zarzut można postawić pracom innych autorów (Komarnicki, 1947; Turlejska, 1972; Orzechowski, 1979). Nowsze spojrzenie zawarto w artykułach, które ukazały się niedawno (Gawron, 2005; Szymankiewicz, 2013). 
W znacznie mniejszym stopniu temat ten obecny jest w literaturze czeskiej, w której dominuje ujęcie ideologiczne uniemożliwiające rzetelne spojrzenie na skomplikowany obraz wojennych relacji emigracyjnych przywódców obu państw (Král, 1953; Kolejka, 1961, s. 461-474). Także w znacznie późniejszych opracowaniach wyraźnie brakuje rzetelnego spojrzenia na omawianą problematykę (Černy, 1979; Janáček, 1962). Na uwagę zasługuje natomiast praca podejmująca kwestie planów powojennej organizacji Europy Wschodniej i Środkowej (Otáhlov, Otáhlov, 1967, s. 163-199). Do tej pory jednak, ani w literaturze polskiej, ani czeskiej, nie pojawiły się analizy założeń ustrojowych projektowanej unii w aspekcie próby zbudowania systemu obrony kolektywnej. Przedstawiany artykuł stanowi próbę zrekonstruowania działań, które miały doprowadzić do stworzenia takiego systemu.

Przedmiotem badań były przede wszystkim projekty aktów normatywnych, w których kreowano organy wspólnotowe dla zamyślanej unii oraz konstruowano zakresy ich funkcjonowania, a także wzajemne relacje między nimi i innymi organami poszczególnych państw tworzących nowy podmiot polityczny. Polska nauka wcześnie wypracowała metodologię badań nad prawem ustrojowym. Już w okresie międzywojennym wskazywano, że w rozważaniach nad prawem ustrojowym powinno się ,z natury rzeczy” stosować metodę prawnodogmatyczną, gdyż pozwala na ustalenie woli prawodawcy czy też projektodawcy (Komarnicki, 1922, s. 1-2). Dzięki tej metodzie możliwe staje się ogólne ustalenie badanych norm i instytucji prawnych. Metoda ta spotyka się z krytyką, gdyż zarzuca się jej, że nie uwzględnia w badaniach czynników społecznych, politycznych, gospodarczych, emocjonalnych itp. (Banaszak, 2004, s. 11). Należy jednak zauważyć, że zazwyczaj metoda ta nie jest jedyną stosowaną w badaniach nad normami prawnymi i zwykle użycie innych metod pozwala uniknąć zjawisk negatywnych. Takim uzupełnieniem była metoda historyczna umożliwiająca umieszczenie badanego problemu w kontekście całego procesu historycznego. Podkreśla się, że badane instytucje ustrojowe należy postrzegać jako produkt dziejowego rozwoju, mające swój określony początek, swoje związane z określonymi warunkami odmiany i drogi rozwoju (Olszewski, 1973, s. 16-17).

Paryska konferencja pokojowa zakończona podpisaniem 28 czerwca 1919 r. traktatu pokojowego miała, w zamyśle głównych autorów, zapewnić pokojowe współistnienie ludom świata na co najmniej kolejne sto lat. Strażnikiem nowego ładu miała być Liga Narodów, pierwsza w dziejach organizacja międzynarodowa strzegąca pokoju globalnego. Dość szybko okazało się, że były to nadzieje płonne. Rozwój ideologii totalitarnych, a w ślad za nimi programów rewizjonistycznych podważał zasadnicze ustalenia traktatu pokojowego. Nowa sytuacja stawała się realnym zagrożeniem dla wielu państw, w tym Europy Środkowej, powstałych w na- 
stępstwie I wojny światowej, szczególnie dla Polski i Czechosłowacji. Oba państwa powstały w efekcie klęski militarnej Niemiec, rozpadu Austro-Węgier oraz procesów rewolucyjnych w Rosji. Oba też od chwili swego powstania musiały mierzyć się z roszczeniami rewindykacyjnymi niektórych swoich sąsiadów. Mimo istnienia pewnych kwestii spornych między nimi samymi naturalna stawała się idea współdziałania w celu zażegnania zagrożeń i podjęcia kroków zmierzających do zbudowania systemu bezpieczeństwa kolektywnego w ramach unii obu państw.

Przywódcy obu państw stosunkowo wcześnie zdali sobie sprawę z kruchości powojennego ładu zbudowanego w Wersalu. Inaczej jednak oceniali sposoby zabezpieczenia interesów narodowych. Praga początkowo dążyła do zachowania i umocnienia ładu powersalskiego i stworzenia systemu bezpieczeństwa chroniącego Republikę Czechosłowacką przed rewizjonizmem węgierskim. Wyrazem tych dążeń było zawiązanie bloku państw zagrożonych rewindykacjami Węgier i ekspansjonizmem Włoch, obejmującego Czechosłowację, Rumunię i Jugosławię, zwanego Małą Ententą (Makowski, 1935, s. 10-11). Jednocześnie zabiegano o utrzymanie poprawnych stosunków i z Berlinem, i z Moskwą. W Warszawie zaś, dostrzegając geopolityczne położenie i szereg nierozwiązanych problemów granicznych, oceniano, że Polska, przy braku dostatecznego zabezpieczenia, będzie najbardziej narażona na agresję ze strony swych największych sąsiadów (Balcerak, 1970, s. 31). Stąd w koncepcjach politycznych pojawiały się projekty struktur regionalnych, obejmujących swym zasięgiem terytoria państw usytuowanych pomiędzy Niemcami a Rosją (Kolendo, 2015, s. 24). Mimo że w obu państwach dostrzegano znaczenie bezpieczeństwa kolektywnego dla utrzymania niepodległości i integralności terytorialnej oraz sprzyjanie takim projektom przez Francję, sojuszniczą zarówno wobec Polski, jak i wobec Czechosłowacji, wzajemna nieufność spowodowała, że obie stolice w okresie międzywojennym nie podjęły żadnych konkretnych kroków w celu zmaterializowania mogącego połączyć je systemu bezpieczeństwa (Zgórniak, 1997, s. 95). Nie mogła tego już zmienić oferta prezydenta Beneša skierowana do prezydenta Rzeczypospolitej Ignacego Mościckiego z 22 września 1938 r. W imieniu strony czechosłowackiej prezydent proponował reset dotychczasowych stosunków wzajemnych, uregulowanie sytuacji Polaków w Republice Czechosłowackiej na zasadzie korekty granic oraz podjęcie współpracy w interesie obu państw i narodów (Pismo Beneša, 1938, k. 14). Z treści pism wyraźnie przebijała presja wywołana kryzysem sudeckim. Strona polska zareagowała 5 dni później. W odpowiedzi prezydent Mościcki skoncentrował się głównie na szybkim rozwiązaniu kwestii terytorialnych w drodze ugody (Pismo Mościckiego, 1938, k. 15). Podjęta w ślad za powyższą wymianą pism korespondencja między ambasadorem polskim w Pradze Kazimierzem Papée a czechosłowackim ministrem spraw zagranicznych Kamilem 
Kroftą nie przyniosła ostatecznie żadnych konkretnych ustaleń (Korespondencja, 1938, k. 16-19).

Idea stworzenia takiego systemu odżyła w całkowicie zmienionej sytuacji politycznej powstałej w rezultacie realizacji ustaleń układu monachijskiego z 30 września 1938 r. i rozpadu państwa czechosłowackiego 15 marca 1939 r. oraz inwazji Rzeszy Niemieckiej i Rosji sowieckiej na Polskę we wrześniu 1939 r. Oba kraje, będąc ofiarami agresywnej polityki Niemiec, stanęły przed koniecznością wypracowania koncepcji powojennej współpracy, która uchroniłaby je w przyszłości przed utratą niepodległości. Dzięki przepisom konstytucyjnym już 30 września 1939 r. w Paryżu udało się, nie bez trudności, dokonać restytucji najwyższych władz państwowych Rzeczypospolitej Polskiej, uznanych przez sojuszników Francję i Wielką Brytanię. Odtworzenie czechosłowackiej emigracyjnej reprezentacji politycznej okazało się problematyczne, głównie ze względu na powstanie kilku ośrodków politycznych, z których każdy aspirował do reprezentowania interesów Republiki Czechosłowackiej. W tych okolicznościach państwa koalicji antyhitlerowskiej unikały wiążących deklaracji i namawiały polityków czeskich i słowackich do rozmów scaleniowych. Należy pamiętać, że po rozpadzie Czechosłowacji 15 marca 1939 r. część polityków czeskich i słowackich udała się na emigrację na zachód Europy. Tam we Francji powołali do życia Słowacką Radę Narodową i Czeską Radę Narodową, które następnie w styczniu 1940 r. połączyły się w Czechosłowacką Radę Narodową. Ośrodek ten był konkurencyjny w stosunku do Czechosłowackiego Komitetu Narodowego kierowanego przez ostatniego prezydenta Republiki Czechosłowackiej Edvarda Beneša. Tymczasowe uznanie tego ośrodka politycznego jako rządu emigracyjnego przez Wielką Brytanię nastąpiło w lipcu 1940 r.

Jeszcze przed wybuchem wojny słowacki polityk Milan Hodža, przebywając w Paryżu, wysunął koncepcję stworzenia unii polsko-czesko-słowackiej (Kisielewski, 1991, s. 22). Projekt ten powtórzył kilka miesięcy później w przekazanym 28 listopada 1939 r. Edwardowi Raczyńskiemu, polskiemu ambasadorowi w Londynie, memorandum poświęconym bezpieczeństwu kolektywnemu w Europie Środkowej. Proponował utworzenie w przyszłości federacji środkowoeuropejskiej składającej się z Czechosłowacji, Polski, Węgier, Rumunii, Bułgarii i Jugosławii. Alians taki miał stanowić zabezpieczenie przed zagrożeniem niemieckim i rosyjskim. Dokument ten przekazany został również zachodnim aliantom. Inicjatywa byłego premiera Czechosłowacji pozostała wówczas bez echa, choć sojusznicy, szczególnie Wielka Brytania, wspierali ideę oparcia powojennego ładu w tej części Europy na regionalnej federacji Polski, Czechosłowacji i Węgier (Kamiński, 2005, s. 22).

Mimo braku konkretów kwestia zbliżenia polsko-czechosłowackiego należała do ważnych, choć nie najważniejszych, zagadnień polskiej polityki zagranicz- 
nej rządu gen. Władysława Sikorskiego. Nie powinno to dziwić, skoro podstawą programową Rządu Jedności Narodowej był program Frontu Morges zawierający postulat stworzenia systemu obronnego skierowanego na wschód i na zachód, zakładający konsensus z południowym sąsiadem jako nieodzowny składnik jego budowy. Warto w tym miejscu zauważyć, że dla premiera realizacja tej idei nie była zupełnie nowa. Sikorski spotkał się z Benešem 2 stycznia 1936 r. w Pradze. Podczas rozmowy miał przedstawić projekt stworzenia bloku państw bałtyckich i bałkańskich z udziałem Polski i Czechosłowacji (Przybylski, 1972, s. 65; Korpalska, 1981, s. 178,188$)$.

Do pierwszych sondażowych rozmów między Sikorskim a Benešem doszło dwa tygodnie po restytucji polskich władz najwyższych w Paryżu. Kolejne prowadzone były miesiąc później, ale już w Londynie podczas wizyty gen. Sikorskiego i ministra spraw zagranicznych Augusta Zaleskiego, w dniach 11 i 12 listopada 1939 r. Premier rządu polskiego ponownie spotkał się z Benešem, wówczas jeszcze osobą prywatną. Wobec tego, że status prawny czeskich i słowackich ośrodków politycznych nie był do końca jasno określony, prowadzone rozmowy polityczne nie mogły wyjść poza ramy niezobowiązującej wymiany poglądów. Mimo że ich charakter był nieoficjalny, dla obu stron miały ważny walor sondażowy. Trwały do połowy następnego roku (Kolendo, 2015, s. 65).

Po upadku Francji w czerwcu 1940 r. polskie najwyższe władze państwowe znalazły się w Wielkiej Brytanii. Wkrótce też doszło do kolejnych kontaktów ze stroną czechosłowacką. Okazją stała się ewakuacja żołnierzy czechosłowackich z terenu Francji. W piśmie datowanym 5 lipca 1940 r. prezydent Beneš dziękował stronie polskiej za pomoc w ewakuacji czechosłowackich lotników na polskich statkach na Wyspy Brytyjskie. Przy tej okazji po raz kolejny wyraził przekonanie o kroczeniu obu narodów tą samą drogą ku wspólnej przyszłości (Pismo Beneša, 1940, k. 20).

W odpowiedzi gen. Sikorski również nawiązał do tego wątku wzajemnych stosunków (Pismo Sikorskiego, 1940, k. 21). Jednakże brak jasnego określenia w kwestii statusu emigracyjnego przedstawicielstwa państwa czechosłowackiego powodowało, że kontakty między politykami obu państw mogły sprowadzać się jedynie do wymiany poglądów, czego wyraz dał Edvard Beneš podczas rozmowy z Edwardem Raczyńskim, polskim ambasadorem w Londynie, odbytej 23 sierpnia 1940 r. Miał wówczas stwierdzić, że „dopóki nie nastąpi konsolidacja wewnętrzna w obozie czeskim, nie widzi możliwości podjęcia praktycznych i ewentualnie wiążących dyskusji [...]" (Notatka Raczyńskiego, 1940, k. 65). Należy przy tym podkreślić, że we wszystkich kontaktach przedstawicieli rządu polskiego z politykami czeskimi i słowackimi na przełomie lat 1939 i 1940 kwestia przyszłej współpracy politycznej, wojskowej i gospodarczej stanowiła stały element (Pisma polityków, 1940, 
k. 22-78). Świadczy to o przywiązywaniu dużej wagi do tej sprawy przez wszystkie strony.

Ważnym gestem ze strony polskiej było uznanie w lipcu 1940 r. tymczasowego rządu czechosłowackiego pod prezydencją Beneša za jedyną legalną reprezentację polityczną Republiki Czechosłowackiej. Uznanie emigracyjnych władz czechosłowackich dało rządowi polskiemu możliwość podjęcia działań na szczeblu ministerialnym. W specjalnej uchwale przyjętej 28 sierpnia 1940 r. polski rząd emigracyjny polecał ministrom spraw zagranicznych oraz informacji i dokumentacji zainicjowanie nowego zbliżenia polsko-czechosłowackiego (Pismo dyrektora, 1940, k. 1). Efektem podjętych działań było podpisanie 11 listopada 1940 r. przez oba rządy wspólnej deklaracji, w której stwierdzano, że „obecna wymiana poglądów na temat przyszłego stowarzyszenia obu krajów dobrze wróży również na przyszłość, łącząc interesy naszych dwóch krajów w sposób trwały" (Uwagi do memorandum, 1940, k. 3-5).

Ostateczne określenie statusu czechosłowackich władz emigracyjnych pozwoliło na podjęcie bardziej skonkretyzowanych działań. W dniu 1 listopada 1940 r. prezydent Beneš przesłał na ręce gen. Sikorskiego memorandum, w którym wyraźnie podkreślił, że „prosty sojusz dwóch państw bez bliższego związku wydaje się być niewystarczający. Będziemy musieli pomyśleć o pewnego rodzaju unii federalnej. W tym nowym systemie współpracy między dwoma państwami konieczne byłoby stworzenie politycznego, dyplomatycznego i administracyjnego mechanizmu każdego rodzaju, który byłby wystarczająco elastyczny, zdolny do rozwoju i zawierałby w swojej strukturze możliwości ewolucji w kierunku możliwie ściślejszego związku" (Wymiana poglądów, 1940, k. 137-146).

Memorandum Beneša zawierało propozycje zasad łączących oba państwa. Zdaniem prezydenta Czechosłowacji oba kraje powinny być połączone $\mathrm{w}$ federację sui generis. Oba narody miały też zachować odrębną państwowość, ze wszystkimi atrybutami suwerenności (odrębni szefowie państw, odrębne parlamenty, odrębne rządy, odrębne armie narodowe). Jedyne ograniczenie suwerenności miałoby dotyczyć unii celnej i wspólnej polityki handlowej oraz unii monetarnej z utrzymaniem odrębnych banków emisyjnych, ale prowadzących wspólną politykę finansową. Federacja powinna prowadzić wspólną politykę zagraniczną przy zachowaniu odrębnych przedstawicielstw dyplomatycznych. Obie armie narodowe miały zachować własne sztaby, lecz zostałby utworzony wspólny Sztab Główny. Jednakowa standaryzacja miałaby objąć wszystkie aspekty funkcjonowania obu sił zbrojnych. Całością funkcjonowania federacji miała kierować Rada, posiadająca kompetencje do kształtowania wspólnej polityki zagranicznej i wojskowej. Ponadto koordynowałaby politykę ekonomiczną, handlową, monetarną i komunikacyjną. Mieli 
ją tworzyć politycy obu krajów: premierzy, ministrowie spraw zagranicznych, finansów i komunikacji. Organami pomocniczymi i technicznymi miały być Rada Ekonomiczna i Rada ds. Komunikacji. Przewidywano również formę współpracy parlamentarzystów, na zasadzie delegacji z obu parlamentów, w celu stworzenia mechanizmu prawodawczego we wszystkich sprawach wspólnych, szczególnie dotyczących polityki zagranicznej, ekonomicznej i wojskowej. Przygotowaniem konkretnych rozwiązań miał się zająć Komitet złożony z czołowych polityków i urzędników najwyższego szczebla obu stron. Komitet ten mógłby proponować tworzenie nowych komitetów i mechanizmów w celu dyskutowania różnych kwestii szczegółowych (Wymiana poglądów, 1940, k. 137-146).

Oczekiwania strony polskiej wyraził premier gen. Sikorski w swoich uwagach do memorandum przekazanego przez prezydenta Beneša. Podzielał pogląd strony czechosłowackiej, dotyczący ustanowienia systemu ścisłej współpracy między obu państwami, która mogłaby przybrać formę konfederacji sui generis. Forma ta miałaby być trwała i należycie zdefiniowana, aby mogła stawiać czoła kryzysom międzynarodowym. Projektowane stowarzyszenie obu państw powinno wdrażać zasadę pełnej solidarności w zakresie wojny i pokoju, przy czym każde z nich podejmowałoby decyzję w tych sprawach za zgodą i przy udziale drugiego państwa (Uwagi do memorandum, 1940, k. 4).

Zbieżne poglądy zaczęły się wkrótce materializować. Już 5 listopada 1940 r. Zaleski przedstawił propozycję powołania dwóch mieszanych polsko-czechosłowackich komitetów: politycznego i ekonomicznego, których zadaniem byłoby opracowanie szczegółów powojennej organizacji obu państw zgodnie z propozycjami prezydenta Beneša (Uwagi Zaleskiego, 1940, k. 94-95). Dalsza konkretyzacja form współpracy nastąpiła w kolejnym piśmie Zaleskiego z 26 listopada 1940 r. Minister proponował w nim utworzenie Komitetu Ustrojowego, którego zadaniem byłoby opracowanie statutu projektowanego związku pod względem politycznym i ekonomicznym. Tym miałyby się zająć składające się na niego komisje: polityczna i ekonomiczna. Ponadto proponował powołanie Komitetu Porozumiewawczego, który bez względu na postęp prac Komitetu Ustrojowego mógłby uzgadniać działania obu rządów (Odpowiedź Zaleskiego, 1940, k. 171-172). Ostatecznie odpowiedź rządu polskiego na memorandum czeskiego przywódcy trafiła do adresata 3 grudnia.

W międzyczasie, na podstawie wspomnianej już deklaracji z 11 listopada, oba rządy powołały do życia struktury, których zadaniem było przygotowanie projektów organizujących przyszłą unię. Utworzono komitety: polityczno-prawny, ekonomiczno-finansowy, wojskowy, polityki społecznej oraz współpracy kulturalnej. Bieżącą współpracą miały się zajmować komitety: polityki zagranicznej, propagan- 
dy oraz wojskowy (Uchwały, 1941, k. 94-97). Całością prac kierował Komitet Koordynacyjny.

Zadanie opracowania zasad konstytucyjnych projektowanego związku państw powierzono Komitetowi Politycznemu Rady Ministrów, na którego czele stanął gen. Kazimierz Sosnkowski, a w jego skład weszli: wicepremier Stanisław Kot, minister sprawiedliwości Marian Seyda, minister spraw zagranicznych August Zaleski, minister oświaty gen. Józef Haller, wicepremier i minister informacji i dokumentacji Stanisław Stroński, ambasador RP w Londynie Edward Raczyński, wiceminister informacji i dokumentacji ks. prałat Zygmunt Kaczyński, minister przemysłu i handlu i minister skarbu Henryk Strasburger, szef Sztabu Naczelnego Wodza płk Tadeusz Klimecki oraz dyrektor Biura Prezydialnego Rady Ministrów Adam Romer. Przygotowanie projektu zasad konstytucyjnych spoczęło w rękach min. Seydy, natomiast część wojskową miał opracować płk Klimecki. Oba projekty miały powstać do 23 stycznia 1941 r. (Protokół, 1941, k. 26).

Ostatecznie min. Seyda przedstawił projekt dopiero 27 stycznia, poprzedzając go obszernym referatem. Wszedł on pod obrady Komitetu Politycznego na posiedzeniu w dniu 11 lutego. W swoim referacie Seyda podkreślał, że związek państw należy budować na gruncie wspólnych realnych interesów państwowych, a nie w imię ogólnikowych haseł ideowych. Wskazywał przy tym, że związek nie powinien obejmować szerokiego kręgu spraw, lecz koncentrować się na kwestiach fundamentalnych dla obu państw, tak aby były one dostatecznie głębokie i solidne, zdolne wytrzymać najcięższe próby (Sprawa, 1941, k. 2-3). Należy w tym miejscu zaznaczyć, że podczas analizy rozwiązań projektowanej unii uwaga skupiona została przede wszystkim na kwestiach związanych z bezpieczeństwem i obronnością.

W tym samym czasie pojawił się dokument określający organizację sił zbrojnych państwa związkowego polsko-czechosłowackiego (Organizacja, 1941, k. 251-254). Według przygotowanych propozycji na czele państwa związkowego miał stać wspólny prezydent posiadający kompetencje najwyższego zwierzchnika sił zbrojnych obu państw. Należy w tym miejscu odnotować, że wariantowo rozważano ustrój monarchiczny, choć podchodzono do tej kwestii dość wstrzemięźliwie z uwagi na nie najlepsze wspomnienia Czechów o rządach Habsburgów. Wspólnym ciałem ustawodawczym miała być Związkowa Rada Państwa, składająca się z reprezentantów ciał ustawodawczych obu państw. Do jej zadań miało należeć rozpatrywanie spraw o zasadniczym znaczeniu dla całego związku oraz uchwalanie ustaw zasadniczych. Funkcje organu wykonawczego Związkowej Rady Państwa miał pełnić rząd centralny złożony z premiera, ministra spraw zagranicznych, ministra obrony państwa, ministra gospodarki oraz ministra komunikacji. Kompetencje ministra gospodarki miały obejmować: finanse, skarb, handel, przemysł 
i rolnictwo, natomiast ministra komunikacji: kolej, transport drogowy i wodny, pocztę i telegraf oraz roboty publiczne.

Do zadań rządu centralnego w sferze przygotowań obronnych należało: określenie politycznych celów wojny, ustalanie głównych wytycznych planu wojny i jego realizacja, przygotowywanie i rozdzielanie potrzebnych środków i zasobów, dokonywanie kontroli przygotowań wojennych. Rząd miał ponosić konstytucyjną i polityczną odpowiedzialność za przygotowanie państwa związkowego do wojny. W czasie wojny rząd miał sprawować ogólne kierownictwo nad wojną jako organ gwarantujący jednolitość i ciągłość polityki wojennej unii. Projekt przewidywał zwiększenie uprawnień premiera w czasie wojny, choć nie zostały one expressis verbis określone.

Rolę organu doradczego i opiniującego $\mathrm{w}$ sprawach przygotowań państwa związkowego do wojny miała pełnić Rada Obrony Państwa, powoływana na czas pokoju. Do jej zadań miało należeć rozpatrywanie wszystkich zasadniczych spraw związanych z przygotowaniem państwa do obrony oraz opiniowanie projektów ustaw w zakresie przygotowań wojennych. Uchwały Rady miały stanowić ogólne wytyczne dla decyzji rządu centralnego. W skład Rady mieli wchodzić: premier rządu centralnego, premierzy rządów krajowych, ministrowie rządu centralnego oraz szef Sztabu Obrony Państwa, w czasie wojny mający pełnić funkcję naczelnego wodza. Bieżącą działalnością Rady miał kierować Sekretariat będący jednocześnie organem studialnym dla szefa rządu centralnego. Zadania Sekretariatu miały polegać na studiowaniu, opracowywaniu i uzgadnianiu spraw mających być przedmiotem obrad Rady, redagowaniu orzeczeń i uchwał Rady oraz prowadzeniu protokołów posiedzeń Rady. W skład Sekretariatu mieli wchodzić wybitni fachowcy, zarówno wojskowi, jak i cywilni. Przewodniczącego miał mianować premier.

Do rzędu najwyższych władz wojskowych zaliczono: ministra obrony państwa, Radę Wojenną, szefa Sztabu Obrony Państwa oraz Sztab Obrony Państwa. Minister obrony państwa wchodził w skład rządu centralnego i do jego zadań miało należeć kierowanie w czasie pokoju całością spraw związanych z przygotowaniami wojennymi oraz administrowanie budżetem unijnym przeznaczonym na realizację planów wojennych opracowanych przez sztab generalny. Natomiast zadaniem Ministerstwa Obrony miało być opracowywanie wszystkich zarządzeń dotyczących wspólnych spraw związanych z dowodzeniem i pokojowym funkcjonowaniem całości sił zbrojnych unii.

Organem doradczym ministra miała być Rada Wojenna, istniejąca tylko w czasie pokoju. Do jej zadań miało należeć rozpatrywanie zasadniczych spraw dotyczących przygotowania sił zbrojnych unii do wojny (rozbudowa sił zbrojnych, organizacja i system mobilizacji, wyposażenie w nowoczesny sprzęt, kierunki 
szkolenia oraz materiałowe i techniczne przygotowanie do wojny), a ponadto wydawanie opinii w sprawach ustalenia pojęć taktycznych i operacyjnych o charakterze doktrynalnym oraz rozpatrywanie zasadniczych spraw dotyczących przygotowań unii do wojny i przygotowywanie odpowiednich dezyderatów sił zbrojnych dla Rady Obrony Państwa. Uchwały Rady Wojennej miały mieć charakter wiążących dyrektyw, w ramach obowiązujących ustaw, dla ministra obrony unii przy podejmowaniu decyzji. W skład Rady Wojennej mieli wchodzić: minister obrony unii jako przewodniczący, szef Sztabu Obrony Państwa jako jego zastępca, obaj ministrowie obrony narodowej, inspektorzy armii, inspektorzy lotnictwa i marynarki, szefowie sztabów wojsk lądowych, lotnictwa i marynarki, generalny kwatermistrz, komendant wyższej szkoły wojennej oraz komendant centrum wyższych studiów wojennych.

Wojskami unii miał dowodzić w czasie pokoju szef Sztabu Obrony Państwa, który był przewidziany na stanowisko naczelnego wodza w czasie wojny. W czasie pokoju podlegał ministrowi obrony państwa, a w czasie wojny premierowi rządu centralnego. Szef Sztabu kierował pracami Sztabu Obrony Państwa oraz inspektorów armii, inspektora lotnictwa i marynarki wojennej. Miał ustalać doktrynalne kierunki szkolenia sił zbrojnych z punktu widzenia potrzeb przyszłej wojny, kierować wyszkoleniem wyższych dowódców i sztabów operacyjnych, opiniować i ustalać obsadę stanowisk wyższych dowódców. Szef Sztabu miał przeprowadzać inspekcje w terenie, organizować i kierować większymi grami wojennymi oraz manewrami wojsk. Sztab generalny mieli tworzyć szefowie sztabów wojsk lądowych, lotnictwa, marynarki wojennej oraz generalny kwatermistrz wraz ze swoimi sztabami. Do jego zadań miało należeć opracowywanie wszelkich wojennych planów wojskowych oraz zestawień potrzeb wojennych, a ponadto prowadzenie niezbędnych prac studialnych, opracowywanie instrukcji i regulaminów, w tym instrukcji szkoleniowych.

Każde z państw tworzących państwo związkowe miało posiadać własne ministerstwo obrony narodowej, którego zadaniem miało być rozstrzyganie wszystkich spraw związanych z dowodzeniem i administracją sił zbrojnych znajdujących się na własnych terytoriach oraz przygotowanie mobilizacji i zaspokajanie wojennych potrzeb sił zbrojnych zgodnie z dyrektywami otrzymywanymi ze sztabu generalnego. Każde państwo na swoim terytorium miało utrzymywać własne wielkie jednostki, jednostki wojsk i służb zgodnie z ustalonym Ordre de Bataille.

Projekt przewidywał ponadto wspólne umundurowanie wojsk obu państw, ujednolicenie stopni wojskowych, ustalenie godła państwa związkowego, jednolitą organizację wszystkich rodzajów wojsk i służb, jednolite wyposażenie w sprzęt i materiały, wspólne wyższe szkolnictwo wojskowe, regulaminy rodzajów wojsk 
i służb oraz jednolite uposażenie. Siły zbrojne miały zachować odrębność w zakresie tradycyjnych znaków narodowych oraz niższego szkolnictwa wojskowego.

Powyższy dokument powstał przed 27 stycznia $1941 \mathrm{r}$. i jego autorem, zgodnie z zapowiedziami, był płk Tadeusz Klimecki, szef Sztabu Naczelnego Wodza. Projektowane rozwiązania uwzględniały postulaty czechosłowackie, ale też odpowiadały poglądom strony polskiej. Przyjęte w dokumencie rozwiązania pozwalają przypuszczać, że opierano się głównie na doświadczeniach polskich. Wyraźne są bowiem odwołania do regulacji konstytucyjnych, a nawet dekretu naczelnego wodza z 1921 r. w kwestii dotyczącej Rady Wojennej. Projekt zakładał istnienie ścisłego organizmu państwowego złożonego z obu państw, przy zachowaniu odrębności poza sferą stosunków międzynarodowych, obronności, gospodarki i finansów. $Z$ jednej strony możemy dostrzec dążenie do znacznego zintegrowania najważniejszych organów państwowych w obszarze obronnym, z drugiej jednak strony odrębne dowództwa narodowe i odrębne jednostki wojskowe. Nie przewidywano tworzenia wspólnych jednostek czy chociażby wymiennego stacjonowania wojsk na swoich terytoriach. Był to zresztą jeden z wariantów i w ocenie gen. Sikorskiego zbyt daleko idący w ówczesnych warunkach politycznych (Organizacja, 1941, k. 251). Propozycja min. Seydy oraz projekt gen. Klimeckiego były przedmiotem około 20 posiedzeń Komitetu Politycznego Rady Ministrów.

Komitet Polityczny przyjął ostateczny projekt Zasad Aktu Konstytucyjnego Związku Polski i Czechosłowacji pod koniec maja 1941 r. Miał on się stać podstawą dwustronnych negocjacji. Jedną z istotnych kompetencji związku państw miała być wspólna obrona. Szczegóły dotyczące wspólnej obrony zapisane zostały w części 10 Zasad (Zasady 1941, k. 25-38). Zakładano powołanie sekretarza stanu obrony Związku, który miał kierować wspólną organizacją przygotowań do obrony Związku. Ponadto miał administrować wspólnym budżetem przeznaczonym na realizację planów wojennych opracowanych przez Sztab Obrony Związku. Sekretarz stanu obrony Związku, na wniosek szefa Związkowego Sztabu Obrony, miał ustalać pokojową dyslokację jednostek wojskowych państw należących do Związku. Miał także przedstawiać prezydentowi Związku wnioski nominacyjne na stopnie generalskie i admiralskie.

Przygotowaniami sił zbrojnych do wojny miał kierować szef Sztabu Obrony Związku. Do jego kompetencji miało należeć kierowanie szkoleniem sił zbrojnych oraz wyszkoleniem wyższych dowódców i sztabów operacyjnych. Miał formułować w czasie pokoju opinie o kandydatach na stopnie generalskie i admiralskie oraz ustalać obsadę wyższych stanowisk dowódczych na czas wojny, przeprowadzać inspekcje jednostek w terenie oraz organizować i kierować grami wojennymi i manewrami sił zbrojnych. Miał także formułować ogólne wytyczne w kwestii mate- 
riałowego i technicznego przygotowania do wojny. Odrzucono zatem koncepcję generalnego inspektora sił zbrojnych jako dowódcy wojska podczas pokoju, co nie powinno dziwić, gdyż Sikorski należał do głównych krytyków takiego rozwiązania. Była to zresztą zasadnicza oś sporu między nim a Piłsudskim.

W ocenie współczesnych precyzyjniej należałoby określić sposób powoływania szefa Sztabu Związku oraz zasady odpowiedzialności, zakres jego działania, jego stosunek do armii narodowych oraz ministrów odpowiedzialnych za sprawy wojska i obrony. Podobnie szczegółowiej należałoby opisać Radę Obrony Związku oraz Radę Wojenną. Nie widziano natomiast potrzeby tworzenia stanowiska Naczelnego Wodza Związku, uważając, że armie narodowe powinny zachować odrębność organizacyjną. Wskazywano przy tym, że projektowane cztery wspólne organy (Związkowa Rada Państwa, rząd centralny, Rada Obrony Państwa i Rada Wojenna) w dostateczny sposób powinny zapewnić siłę odporną Związku i skuteczność natychmiastowego jej działania. Wojskowi obu krajów uznali, że wspólne organy polityczne Związku zapewnią siłę zbrojną działającą szybko i skutecznie (Uwagi do projektu, 1941, k. 50).

Obie strony sformalizowały rozmowy na temat przyszłej konfederacji. Ostatniego dnia stycznia 1941 r. powołano do życia Komitet Koordynacyjny Polsko-Czechosłowacki, wyznaczając mu rolę najważniejszego organu współpracy obu rządów i zadanie formułowania zaleceń dla administracji rządowych. Mimo deklaracji o priorytetowym traktowaniu sprawy przyszłego Związku Komitet Koordynacyjny w ciągu pierwszego półrocza $1941 \mathrm{r}$. zebrał się jedynie kilka razy i koncentrował się przede wszystkim na drugorzędnych sprawach organizacyjnych. Utworzono komitety pomocnicze, których zadaniem było prowadzenie dalszych studiów związanych z pracami nad projektem Związku Polski i Czechosłowacji. Należały do nich komitety: Polityczno-Prawny, Gospodarczo-Finansowy, Polityki Społecznej, Współpracy Kulturalnej oraz Wojskowy. Ponadto utworzono komitety: Spraw Zagranicznych, Propagandy oraz Wojskowy w celu współdziałania w sprawach bieżących (Wandycz, 1956, s. 128-129). Ta wyraźna wstrzemięźliwość w kontaktach wynikała z odmiennego podejścia negocjacyjnego reprezentantów obu państw.

Strona polska nie miała jasno sprecyzowanego poglądu na temat zakresu unijnych powiązań Polski i Czechosłowacji. Członkowie Komitetu Politycznego balansowali między ideą zbudowania po wojnie ścisłej unii na gruncie powiązań politycznych i gospodarczych, nawet za cenę ograniczenia suwerenności, a zupełnie luźną formą związku państwowego. Strona czechosłowacka opowiadała się raczej za konstrukcją federacyjną pozwalającą na zachowanie znacznej autonomii szczególnie w sferze ekonomicznej, co pozwalało na zrównoważenie przewagi polityczno-demograficznej północnego sąsiada. Ponadto Czesi i Słowacy obawiali się, że 
przyszła unia może stać się narzędziem polityki wymierzonej przeciwko Niemcom, a przede wszystkim Rosji (Kolendo, 2015, s. 126-127). Obie strony, siadając do stołu negocjacyjnego, stojąc na tak rozbieżnych stanowiskach, nie mogły liczyć na szybkie osiągnięcie konsensusu. Zwłaszcza że zadawnione spory graniczne i stosunek do Śląska Cieszyńskiego nie rokowały pełnej normalizacji we wzajemnych stosunkach i w konsekwencji trwałego zbliżenia.

$\mathrm{Na}$ dalszych negocjacjach zaciążyła agresja III Rzeszy na Związek Sowiecki w czerwcu $1941 \mathrm{r}$. i znalezienie się potężnego sojusznika po stronie aliantów, obie strony bowiem musiały uzgodnić wspólną płaszczyznę wobec dyplomacji sowieckiej, co nie było łatwe. Na polskim stanowisku wobec nowego alianta piętnem odcisnęła się agresja z 17 września 1939 r. i nielegalne zagarnięcie wschodnich ziem II Rzeczypospolitej. Natomiast Czesi i Słowacy, pozostając w błędnym przekonaniu co do intencji strony sowieckiej, bezkrytycznie uznawali wschodniego sąsiada za gwaranta odbudowy niepodległego państwa czechosłowackiego, i to w granicach sprzed układu monachijskiego (Beneš, 1947, s. 9). W nowych realiach politycznych i wojennych zbliżenie czechosłowacko-sowieckie nie mogło pozostać bez wpływu na dalsze negocjacje federacyjne polsko-czechosłowackie, tym bardziej że dyplomacja sowiecka podkreślająca antyniemiecki i antyrosyjski charakter koncepcji unijnych torpedowała wszelkie projekty strony polskiej i czechosłowackiej, a zwłaszcza powojenne plany związkowe. W rezultacie emigracyjny rząd Czechosłowacji zaczął wycofywać się ze wspólnych planów polsko-czeskich. Ilustracją tego stanowiska może być uwaga wieloletniego szefa czechosłowackiej misji dyplomatycznej w Moskwie Zdenka Fierlingera: „Byłbym niezmiernie zaskoczony, gdybyśmy w związku ze zmianą stosunków, to jest przy naszym nowym spójnym stosunku do Związku Sowieckiego, chcieli wracać do starych planów konfederacyjnych z Polską. Dobrze czułem, że podobne plany [...] będą w Moskwie poczytane za nieprzyjazne i będą oddalać nas od Związku Sowieckiego, nie mówiąc już o innych trudnościach w rozwoju wewnętrznym, gdyby doszły do skutku" (Fierlinger, 1949, s. 44).

Ostateczny kres negocjacjom obu rządów w sprawie powojennego zbliżenia polityczno-wojskowego położyło ogłoszenie 14 sierpnia 1941 r., podpisanej dwa dni wcześniej na pokładzie brytyjskiego pancernika „Prince of Wales” przez premiera Zjednoczonego Królestwa Winstona Churchilla i prezydenta Stanów Zjednoczonych Ameryki Franklina Delano Roosevelta, Karty Atlantyckiej oraz ustalenia międzynarodowej konferencji w Londynie 24 września tego samego roku przewidujące powojenne gwarancje pokoju (Kowalski, 1973, s. 72-80). 
Próby stworzenia unii polsko-czechosłowackiej wpisywały się w szerszy kontekst poszukiwania formy organizacyjnej dla obrony kolektywnej na kontynencie europejskim. W latach 20. popularność zyskiwała koncepcja Paneuropy autorstwa austriackiego dyplomaty hr. Richarda von Coudenhove-Kalergiego (Tombiński, 1995, s. 84; Haręża, 2002, s. 267-268; Bożym, 2007, s. 82-83). Projekt sfederalizowanych narodów Europy przedstawił 7 września 1929 r. na forum Ligi Narodów Aristide Briand, minister spraw zagranicznych Francji. Projekt ten był oparty na solidarności, dążeniu do prosperity oraz politycznej i społecznej współpracy. W roku następnym na zlecenie Ligi Briand zaprezentował Memorandum o organizacji systemu Federalnej Unii Europejskiej. Jego propozycja zakładała federację tworzoną przez Francję, Wielką Brytanię i Niemcy oraz inne państwa europejskie. Nie mogły do niej należeć Rosja i Turcja. Miała się ona opierać na unii celnej, wspólnym rynku oraz wspólnym systemie bezpieczeństwa. Federacja miała posiadać własne organy: Konferencję Polityczną, Stały Komitet Polityczny (organ wykonawczy) oraz Sekretariat. Własną koncepcję federacji środkowoeuropejskiej opracował w początkach lat 20. ubiegłego wieku Władysław Sikorski. Jego inicjatywa odwoływała się do idei Międzymorza i zakładała utworzenie federacji, do której miały należeć: Polska, państwa bałtyckie, państwa bałkańskie, Czechosłowacja, Węgry i Białoruś.

\section{Bibliografia:}

Balcerak, W. (1970). Koncepcje integracyjne w polskiej polityce zagranicznej (1918-1939). Dzieje Najnowsze, 1, 31-56.

Banaszak, B. (2004). Prawo konstytucyjne. Warszawa: C.H. Beck.

Batowski, H. (1984). Z dziejów dyplomacji polskiej na obczyźnie (wrzesień 1939-lipiec 1941). Kraków-Wrocław: Wydawnictwo Literackie.

Beneš, E. (1947). Pamèti. Od Mnichova k nové válce a k novému vitězstvi. Praha: Orbis.

Borzym, A. (2007). Polscy Ojcowie Europy. Warszawa: Wydawnictwo Trio.

Černy, J. (1979). Nová orientacia zabtaničnej polityky Čskoslovenska (1939-1948). Praha.

Fierlinger, Z. (1949). Ve službách ČSR. Od prépadeni SSSRdo konce druhé svètové války. Praha: Nakladatelství Svoboda.

Gawron, K. (2005). Stosunki polsko-czechosłowackie w latach 1918-1939 jako przyczynek do badań nad konfederacją polsko-czechosłowacką 1939-1943. Historia i Polity$k a, 1,74-78$. DOI: 10.12775/HiP.2005.003.

Haręża, G. (2002). Z problematyki paneuropeizmu w Drugiej Rzeczypospolitej. W: M. Maciejewski, M. Marszał (red.). Doktryny polityczne i prawne u progu XXI wieku. Wybrane problemy badawcze (s. 267-268). Wrocław: Kolonia Limited. 
Janáček, F. (1962). Dva smery v začiatkoch národného odboja (október 1939-jún 1940), Bratislava.

Kamiński, M.K. (2005). Edvard Beneš kontra gen. Wtadystaw Sikorski. Polityka wtadz czechostowackich na emigracji wobec rządu polskiego na uchodźstwie 1939-1943. Warszawa: Neriton.

Kisielewski, T. (1991). Federacja środkowo-europejska. Pertraktacje polsko-czechostowackie 1939-1943. Warszawa: Ludowa Spółdzielnia Wydawnicza.

Kolejka, J. (1961). Československo-polské vztahy za druhé světově války. Slezký Sbor$n i k, 4$.

Kolendo, I.T. (2015). Unia polsko-czechostowacka. Projekt z lat 1940-1943. Ukochane dziecko premiera gen. Wtadystawa Sikorskiego. Łódź: Księży Młyn Dom Wydawniczy Michał Koliński.

Komarnicki, T. (1947). Próby stworzenia Związku Polsko-Czeskiego w okresie II wojny światowej. Sprawy Międzynarodowe, 2-3, 4.

Komarnicki, T. (1948). Próby stworzenia Związku Polsko-Czeskiego w okresie II wojny światowej. Sprawy Międzynarodowe, 1.

Komarnicki, W. (1922). Polskie prawo polityczne. Warszawa: F. Hoesick.

Korpalska, W. (1981). Wtadystaw Eugeniusz Sikorski. Biografia polityczna. Wrocław: Zakład Narodowy im. Ossolińskich.

Kowalski, W.T. (1973). Wielka Koalicja 1941-1945, t. 1. Warszawa: Wydawnictwo Ministerstwa Obrony Narodowej.

Kowalski, W.T. (1979). Walka dyplomatyczna o miejsce Polski w Europie 1939-1945. Warszawa: Książka i Wiedza.

Král, V. (1953). O Masarykové a Benešové kontrrevoluni protisoveštské polityce. Praha: SNPL - Státní nakladatelství politické literatury.

Makowski, J. (1935). Wspótczesne formy bezpieczeństwa zbiorowego. Warszawa: s.n.

Olszewski, H. (1973). Podejście historyczne w prawoznawstwie. W: A. Łopatka (red.). Metody badania prawa (s. 16-17). Wrocław-Warszawa-Kraków-Gdańsk: Zakład Narodowy im. Ossolińskich.

Orzechowski, M. (1979). Czechosłowacja w polskiej myśli politycznej w okresie II wojny światowej. W: Polska myśl polityczna XIX i XX wieku. Polska i jej sąsiedzi, t. 1. Wrocław: Ossolineum.

Otáhlov, L., Otáhlov, M. (1967). K problematice plánů na uspořadáni stř̌edni a východni Evropy. Sbornik Historický, 15.

Przybylski, H. (1972). Front Morges w okresie II Rzeczypospolitej. Warszawa: PWN.

Szymankiewicz, B. (2013). Koncepcje sojuszy polsko-czechosłowackich 1919-1943. Historia Slavorum Occidentis, 1(4), 165-178.

Tombiński, J. (1995). Początki ruchu paneuropejskiego w Polsce. Prace Historyczne, 118, 83-93.

Turlejska, M. (1972). Spór o Polskę. Szkice historyczne. Warszawa: Czytelnik.

Wandycz, P.S. (1956). Czechoslovak-Polish Confederationand the Great Powers 1940-1943. Bloomington: Greenwood Press.

Zabiełło, S. (1970). O rzad i granice. Walka dyplomatyczna o sprawe polska w II wojnie światowej. Warszawa: Instytut Wydawniczy Pax. 
Zgórniak, M. (1997). Z problematyki polityczno-wojskowej Polski i Czechosłowacji w latach 1921-1938. W: M. Pułaski (red.). Z dziejów Europy Środkowej w XX wieku. Studia ofiarowane Henrykowi Batowskiemu w 90. rocznicę urodzin (s. 95-108). Kraków: Wydawnictwo Uniwersytetu Jagiellońskiego.

\section{Źródła archiwalne:}

Korespondencja między ambasadorem RP w Pradze Kazimierzem Papée i ministrem spraw zagranicznych Czechosłowacji Kamilem Kroftą, Archiwum Instytutu Polskiego i Muzeum Sikorskiego w Londynie, Zespół Prezydium Rady Ministrów, sygn. 19, k. $16-19$.

Notatka ambasadora Edwarda Raczyńskiego z rozmowy z prezydentem Republiki Czeskiej w dniu 23 sierpnia 1940 r., Archiwum Instytutu Polskiego i Muzeum Sikorskiego w Londynie, Zespół Prezydium Rady Ministrów, sygn. 19, k. 65.

Odpowiedź ministra Augusta Zaleskiego na pismo premiera Sikorskiego z dnia 25 listopada 1940 r. w sprawie odpowiedzi stronie czechosłowackiej z dnia 26 listopada 1940 r., Archiwum Instytutu Polskiego i Muzeum Sikorskiego w Londynie, Zespół Prezydium Rady Ministrów, sygn. 19, k. 171-172.

Organizacja Sił Zbrojnych Państwa Związkowego Polsko-Czechosłowackiego. Archiwum Instytutu Polskiego i Muzeum Sikorskiego w Londynie, Zespół Prezydium Rady Ministrów. Sygn. 19, k. 251-254.

Pisma różnych polityków i urzędników kierowanych do gen. Sikorskiego w sprawach czechosłowackich, Archiwum Instytutu Polskiego i Muzeum Sikorskiego w Londynie, Zespół Prezydium Rady Ministrów, sygn. 19, k. 22-78.

Pismo dyrektora Biura Prezydialnego Rady Ministrów z dnia 2 września 1940 r. informujące o podjęciu przez Radę Ministrów uchwały o zainicjowaniu nowego zbliżenia polsko-czechosłowackiego, Archiwum Instytutu Polskiego i Muzeum Sikorskiego w Londynie, Zespół Prezydium Rady Ministrów, sygn. PRM K 15, k. 1.

Pismo gen. Sikorskiego do prezydenta Beneša z dnia 9 lipca 1940 r., Archiwum Instytutu Polskiego i Muzeum Sikorskiego w Londynie, Zespół Prezydium Rady Ministrów, sygn. 19, k. 21.

Pismo prezydenta Beneša do premiera Sikorskiego z dnia 5 lipca 1940 r., Archiwum Instytutu Polskiego i Muzeum Sikorskiego w Londynie, Zespół Prezydium Rady Ministrów, sygn. 19, k. 20.

Pismo prezydenta Czechosłowacji Edvarda Beneša do prezydenta Rzeczypospolitej Polskiej z dnia 22 września 1938 r., Archiwum Instytutu Polskiego i Muzeum Sikorskiego w Londynie, Zespół Prezydium Rady Ministrów, sygn. 19, k. 14.

Pismo prezydenta Mościckiego do prezydenta Beneša z dnia 27 września 1938 r., Archiwum Instytutu Polskiego i Muzeum Sikorskiego w Londynie, Zespół Prezydium Rady Ministrów, sygn. 19, k. 15.

Protokół posiedzenia Komitetu Politycznego z dnia 14 stycznia 1941 r., Archiwum Instytutu Polskiego i Muzeum Sikorskiego w Londynie, Zespół Prezydium Rady Ministrów, sygn. PRM 38B, k. 26. 
Sprawa ustroju związku państwowego w Europie Środkowej - referat Mariana Seydy z dnia 27 stycznia 1941 r., Archiwum Instytutu Polskiego i Muzeum Sikorskiego w Londynie, Zespół Prezydium Rady Ministrów, sygn. PRM 38C, k. 2-3.

Uchwały Komitetu Politycznego z dnia 14 marca 1941 r., Archiwum Instytutu Polskiego i Muzeum Sikorskiego w Londynie, Zespół Prezydium Rady Ministrów, sygn. PRM 38B, k. 94-97.

Uwagi Augusta Zaleskiego do projektu Beneša z dnia 5 listopada 1940 r., Archiwum Instytutu Polskiego i Muzeum Sikorskiego w Londynie, Zespół Prezydium Rady Ministrów, sygn. 19, k. 94-95.

Uwagi do memorandum Jego Ekscelencji Prezydenta Republiki Czechosłowackiej z dnia 1 listopada 1940 r., Archiwum Instytutu Polskiego i Muzeum Sikorskiego w Londynie, Zespół Prezydium Rady Ministrów, sygn. PRM K 15, k. 3-5.

Uwagi do projektu Aktu Konstytucyjnego Związku Polski i Czechosłowacji, Archiwum Instytutu Polskiego i Muzeum Sikorskiego w Londynie, Zespół Prezydium Rady Ministrów, sygn. PRM 38C, k. 50.

Wymiana poglądów na temat współpracy polsko-czechosłowackiej po obecnej wojnie, memorandum prezydenta Beneša z dnia 1 listopada 1940 r., Archiwum Instytutu Polskiego i Muzeum Sikorskiego w Londynie, Zespół Prezydium Rady Ministrów, sygn. 19, k. 80-90. Tekst polski memorandum, IPMS, PRM sygn. 19, k. 137-146.

Zasady Aktu Konstytucyjnego Związku Polski i Czechosłowacji, Archiwum Instytutu Polskiego i Muzeum Sikorskiego w Londynie, Zespół Prezydium Rady Ministrów, sygn. PRM 38C, k. 25-38. 